\title{
Cardiopulmonary function in patients with pulmonary hypertension
}

\author{
Nikos Gazetopoulos, ${ }^{1}$ Nikos Salonikides, ${ }^{2}$ and Hywel Davies ${ }^{3}$ \\ From the Cardiac Department, Guy's Hospital, London; and Nosileutikon Idryma M.T.S., Athens, Greece
}

The effects of pulmonary hypertension on cardiopulmonary function were investigated by ventilatory, haemodynamic, and metabolic studies at rest and during exercise. The studies were carried out in 12 patients with primary, thromboembolic, or residual pulmonary hypertension after surgical closure of intracardiac defects, and in II patients with pulmonary hypertension secondary to obstructive lung disease. The findings have been compared with earlier published results of similar studies, performed in other situations associated with pulmonary hypertension.

The cardiac output is reduced in most forms of pulmonary hypertension. A relation was found between the reduction in exercise output and the level of pulmonary arterial pressure. Exceptions occur, indicating the contribution of additional factors to the circulatory response.

Lung function tests usually gave normal results in primary thromboembolic and residual pulmonary hypertension. The variability of findings in the different conditions associated with pulmonary hypertension suggests that increased pulmonary arterial pressure, per se, has no effect on lung function.

Some degree of exercise hyperventilation is present in most forms of pulmonary hypertension. This is usually pronounced in primary and thromboembolic pulmonary hypertension but it is less pronounced in obstructive lung disease.

The factors determining exercise ventilation in the various forms of pulmonary hypertension are discussed. Evidence is given that tissue hypoxia may be implicated in the genesis of the mild hyperventilation seen in lung disease. In primary and thromboembolic pulmonary hypertension the haemodynamic abnormalities, changes in arterial blood composition, or tissue hypoxia are apparently not responsible for the excessive ventilatory response. It is believed that hyperventilation in these conditions is a consequence of abnormal receptor impulses from the lungs.

The study of functional disturbances in patients with pulmonary hypertension has attracted the attention of many investigators and several reports have been published over the past few years. Particularly intriguing is the exercise hyperventilation seen in some of these patients.

In previous papers, we have described the respiratory, circulatory, and biochemical changes, at rest and on effort, in patients with pulmonary hypertension accompanying left heart disease (Gazetopoulos, Davies, and Deuchar, 1966a), left-to-

\footnotetext{
Received 25 June 1973.

1 Present address: Aretaeion Hospital, University of Athens, Greece.

2 Present address: Nosileutikon Idryma M.T.S., Athens, Greece.

${ }^{3}$ Present address: University of Colorado Medical Center, Denver, Colorado, U.S.A.
}

right shunts (Gazetopoulos and Davies, 1966), and Eisenmenger syndromes (Davies and Gazetopoulos, 1965, 1966a).

We now present the results of similar studies on patients with primary, thromboembolic, or residual postoperative pulmonary hypertension and in patients with pulmonary hypertension accompanying obstructive lung disease. No attempt has been made to separate primary from thromboembolic pulmonary hypertension since the pathophysiological features of both conditions are similar and their differentiation is difficult and often impossible (Evans, Short, and Bedford, 1957; Rosenberg, 1964; Fowler et al., 1966; Storstein et al., 1966; Walcott, Burchell, and Brown, 1970; Trell, 1972).

Particular attention is given to the interrelation of the various disturbances and their effects on exercise ventilation. 
TABLE I Clinical details of subjects studied

\begin{tabular}{|c|c|c|c|c|c|c|c|c|c|}
\hline Case No. & Sex & $\begin{array}{l}\text { Age } \\
(y r)\end{array}$ & $\begin{array}{l}B S A \\
\left(m^{2}\right)\end{array}$ & $\begin{array}{l}\text { Oxygen } \\
\text { capacity } \\
(\text { vol \%) }\end{array}$ & $\begin{array}{l}\text { Disability } \\
\text { grade }\end{array}$ & \multicolumn{4}{|c|}{ Diagnosis } \\
\hline I & $\mathbf{F}$ & 34 & $\mathbf{r} \cdot 7$ & $18 \cdot 1$ & 3B & \multicolumn{4}{|c|}{ Primary/thromboembolic hypertension } \\
\hline $2 a$ & $\mathbf{M}$ & 55 & $2 \cdot \mathbf{I}$ & $2 \mathrm{I} \cdot 4$ & 2 & , & & & " \\
\hline $2 b$ & $\mathbf{M}$ & 58 & $2 \cdot 1$ & $20 \cdot 0$ & 3A & و & & & " \\
\hline 3 & $\mathbf{M}$ & 50 & $\mathrm{I} \cdot 7$ & 19.9 & 3B & " & & & " \\
\hline 4 & $\mathrm{~F}$ & 45 & $I \cdot 6$ & $19 \cdot 4$ & 3B & , & & & 》 \\
\hline 5 & $\mathrm{M}$ & $6 \mathrm{I}$ & I.7 & $21 \cdot 7$ & 3B & " & & & " \\
\hline 6 & $\mathrm{M}$ & 44 & $1 \cdot 7$ & $21 \cdot 7$ & $3 \mathrm{~A}$ & , & & & " \\
\hline 7 & $\mathrm{~F}$ & $4 I$ & $I \cdot 4$ & $2 I \cdot 2$ & 2 & , & & & " \\
\hline 8 & $\mathrm{~F}$ & 62 & $I \cdot 6$ & $19 \cdot 4$ & $3 \mathrm{~A}$ & و & & & " \\
\hline 9 & $\mathrm{~F}$ & 40 & $\mathrm{I} \cdot 8$ & $17 \cdot 6$ & 3B & " & & & " \\
\hline 10 & $\mathrm{~F}$ & 37 & $\mathrm{I} \cdot 8$ & $18 \cdot 4$ & 3B & \multirow{4}{*}{\multicolumn{4}{|c|}{$\begin{array}{l}\text { Postoperative, atrial septal defect } \\
\text { Postoperative, persistent ductus arteriosus } \\
\text { Postoperative, ventricular septal defect } \\
\text { Chronic obstructive pulmonary disease }\end{array}$}} \\
\hline II & $\mathbf{M}$ & 21 & $1 \cdot 7$ & 23.6 & 2 & & & & \\
\hline I2 & $\mathbf{M}$ & 16 & $1 \cdot 3$ & 20.5 & 2 & & & & \\
\hline 13 & $\mathrm{M}$ & 38 & $1 \cdot 7$ & 19.6 & $3 B$ & & & & \\
\hline 14 & $M$ & 58 & $2 \cdot 0$ & $20 \cdot 1$ & $3 A$ & " & , & و & " \\
\hline 15 & $M$ & 61 & $1 \cdot 9$ & 18.6 & $3 \mathrm{~A}$ & " & ", & " & " \\
\hline 16 & $\mathbf{F}$ & 57 & $I \cdot 7$ & $20 \cdot 4$ & 3B & , & " & " & " \\
\hline 17 & $\mathbf{M}$ & 55 & $2 \cdot 0$ & $22 \cdot 2$ & $3 \mathrm{~A}$ & , & " & $"$ & " \\
\hline 18 & $\mathbf{M}$ & 51 & $1 \cdot 8$ & $18 \cdot 7$ & $3 \mathrm{~A}$ & ", & " & " & " \\
\hline 19 & $\mathbf{F}$ & 33 & $\mathrm{I} \cdot 5$ & 18.6 & $3 A$ & " & , & " & " \\
\hline 20 & $\mathbf{F}$ & 39 & $I \cdot 6$ & $25 \cdot 0$ & 2 & , & , & " & " \\
\hline 21 & $\mathbf{F}$ & 54 & $\mathrm{I} \cdot 6$ & 19.2 & $3 A$ & " & , & " & " \\
\hline 22 & $\mathbf{M}$ & 62 & $\mathrm{I} \cdot 8$ & 19.8 & 2 & " & פ, & " & " \\
\hline 23 & $\mathbf{F}$ & $5 I$ & $I \cdot 5$ & $21 \cdot 7$ & $3 \mathrm{~A}$ & , & , & " & " \\
\hline
\end{tabular}

Note: Grade of disability according to New York Heart Association, Grade 3 being divided into 3 A and 3 B after Donald, Bishop, and Wade (1954).

\section{Subjects and methods}

Twenty-three patients were studied. Cases $\mathrm{I}-9$ had primary or thromboembolic pulmonary hypertension, Cases 10-12 had residual pulmonary hypertension after surgical closure of intracardiac defects, and Cases 13-23 had pulmonary hypertension in association with chronic obstructive lung disease. Patients with pulmonary venous hypertension or a shunt in either direction were thus excluded. One patient (Case 2) was studied twice. At the time of the second study, 3 years after the first, his clinical condition had deteriorated and congestive heart failure had appeared. Clinical data on patients studied are shown in Table $I$.

All patients were investigated at Guy's Hospital, London or at Nosileutikon Idryma M.T.S., Athens. The techniques of study in both centres were similar, with only minor differences, and details of these have been given previously. Lung function was studied by techniques described by Davies and Gazetopoulos (1967), predicted values being taken from Bates, Macklem, and Christie (I97I). Haemodynamic and ventilatory measurements at rest and on effort were made during cardiac catheterization by standard techniques (Gazetopoulos et al., 1966b). Arterial blood oxygen saturation, $p \mathrm{H}$, $\mathrm{PCO}_{2}$, lactate, and pyruvate were estimated by methods described by Davies, Gazetopoulos, and Oliver (1965).

Exercise was performed in the supine position and lasted for ro minutes. All measurements were made simultaneously after the 5 th minute of constant exercise when a steady state had been reached. The exercise load was low (100-400 kpm/min), being set according to the ability of each patient. If the patient were able to complete one exercise level without distress, the load was increased and the measurements were repeated during exercise of the same duration.

\section{Results}

Table I shows the clinical characteristics of the patients. Table 2 shows the results of the lung function tests. There is little abnormality of the measured respiratory parameters in patients with primary, thromboembolic, and residual pulmonary hypertension. Table 3 shows the ventilatory and haemodynamic findings and the arterial blood composition at rest and on effort.

The relation between exercise oxygen uptake and cardiac output is shown in Fig. I. Cardiac output is reduced in patients with primary, thromboembolic, and residual pulmonary hypertension, though in the group with lung disease there is little or no reduction. Fig. 2 shows the relation between pulmonary arterial pressure and reduction in cardiac output, expressed in litres per minute, below the mean predicted value for the given exercise oxygen uptake. In general, an inverse relation is seen. The patient, 
TABLE 2 Lung function data

\begin{tabular}{|c|c|c|c|c|c|c|c|c|}
\hline $\begin{array}{l}\text { Case } \\
\text { No. }\end{array}$ & $\begin{array}{l}\text { Vital cap- } \\
\text { acity: \% } \\
\text { deviation } \\
\text { from } \\
\text { predicted }\end{array}$ & $\begin{array}{l}\text { Functional } \\
\text { residual } \\
\text { capacity: } \\
\% \text { deviation } \\
\text { from } \\
\text { predicted }\end{array}$ & $\frac{R V^{\star}}{T L C} \times 100$ & $\begin{array}{l}\text { Maximal } \\
\text { breathing } \\
\text { capacity: } \\
\% \text { deviation } \\
\text { from } \\
\text { predicted }\end{array}$ & $\frac{F E V_{1.0 \dagger}}{V C} \times 100$ & $\begin{array}{l}\text { Compliance } \\
\text { l. } / \mathrm{cm} \mathrm{H}_{2} \mathrm{O}\end{array}$ & $\begin{array}{l}\text { Distribution } \\
\mathrm{N}_{2} \% 750- \\
1250 \ddagger\end{array}$ & $\begin{array}{l}\text { Diffusing cap- } \\
\text { acity }(C O \\
\text { uptake } \%)\end{array}$ \\
\hline I & +17 & +5 & 21 & + I0 & 76 & - & 2 & 42 \\
\hline $2 a$ & -26 & -8 & 39 & -17 & 70 & - & I & 46 \\
\hline $2 b$ & -35 & -17 & 43 & -27 & 67 & - & 3 & 40 \\
\hline 3 & -33 & -20 & 34 & -33 & 71 & - & 2 & - \\
\hline 4 & -24 & - & - & +7 & 80 & 0.133 & - & 52 \\
\hline 5 & -13 & +10 & 46 & $+r$ & 75 & 0.083 & - & 60 \\
\hline 6 & -27 & -15 & 36 & -25 & 80 & - & - & - \\
\hline 7 & +5 & -4 & 36 & -8 & 78 & 0.205 & 2 & 46 \\
\hline 8 & -19 & - & - & +4 & 84 & 0.108 & I & 57 \\
\hline 9 & -3 & - & - & -2 & 75 & 0.250 & - & 55 \\
\hline 10 & +4 & +13 & 30 & -4 & 77 & 0.105 & - & - \\
\hline II & -10 & -15 & 35 & +8 & 80 & - & $\mathbf{I}$ & - \\
\hline 13 & -48 & -27 & 51 & -64 & 57 & - & 8 & $4 I$ \\
\hline 14 & $-4 I$ & -4 & 54 & -78 & 40 & - & - & - \\
\hline 15 & -23 & +49 & 58 & -79 & 29 & - & 10 & 37 \\
\hline 16 & -38 & + 10 & 50 & -62 & 48 & - & 8 & - \\
\hline 17 & -50 & -18 & 48 & -60 & $4 I$ & 0.098 & Io & 42 \\
\hline 18 & $-4 I$ & - & - & -69 & 36 & 0.126 & - & 46 \\
\hline 19 & -62 & -9 & 62 & -74 & 54 & - & - & 35 \\
\hline 20 & -49 & +13 & 58 & -65 & 48 & 0.076 & - & 45 \\
\hline 21 & -44 & - & - & -57 & 52 & 0.062 & - & 46 \\
\hline 22 & -29 & +22 & 55 & -68 & 50 & 0.110 & 6 & 50 \\
\hline 23 & -59 & - & - & -67 & 57 & - & 7 & - \\
\hline
\end{tabular}

Note: Air distribution was measured by the single-breath method (Comroe and Fowler, 195I). Diffusing capacity was estimated by the measurement of the fractional CO uptake (Bates, 1952).

$\star \mathrm{RV}=$ reisdual volume; $\mathrm{TLC}=$ total lung capacity.

$+\mathrm{FEV}=$ forced expiratory volume; $\mathrm{VC}=$ vital capacity.

$¥$ Normal values for distribution are $1-2$ per cent and for $C O$ uptake are 35-55 per cent, decreasing with age. The fraction of CO removed is expressed as percentage and is calculated by the formula: $\frac{\text { F. Insp. CO-F. Expir. CO }}{\text { F. Inspir. CO }}$

however, with the highest pulmonary arterial pressure (Case 2a) shows the least reduction in cardiac output among all patients with primary and thromboembolic pulmonary hypertension.

In Fig. 3 the relation between minute ventilation and oxygen uptake on effort is seen. An obvious exercise hyperventilation is noted in most patients with primary or thromboembolic pulmonary hypertension, though there are some exceptions. The degree of hyperventilation, expressed in litres per minute above the mean predicted value for the given exercise oxygen uptake, was plotted against the pulmonary arterial systolic pressure, the total pulmonary vascular resistance, and the degree of reduction of cardiac output in Fig. 4, 5, and 6, respectively. No relation is seen. Fig. 7 shows the main findings in the two studies of Case 2. Heart failure developed during 3 years between the two studies. Hyperventilation on effort became more pronounced, cardiac output fell, and lactate production increased. In Fig. 8 the degree of exercise hyper- ventilation has been plotted against lactate levels. For comparison, we have included in this Figure, the relevant findings from patients with isolated pulmonary stenosis where tissue hypoxia, evidenced by lactate production, is likely to be the sole determining factor of exercise hyperventilation (see Discussion). It is seen that in primary and thromboembolic pulmonary hypertension the ventilatory response is, as a rule, much greater than in patients with pulmonary stenosis having a similar degree of lactic acidaemia. In the patients with lung disease and in 2 of the 3 with residual pulmonary hypertension the pattern of response seems similar to pulmonary stenosis. The third subject of the last group (Case ro) had evidence of pulmonary embolism. None of the other haemodynamic or biochemical factors seemed to be associated with the degree of hyperventilation.

\section{Discussion}

Pulmonary arterial hypertension occurs in a variety 


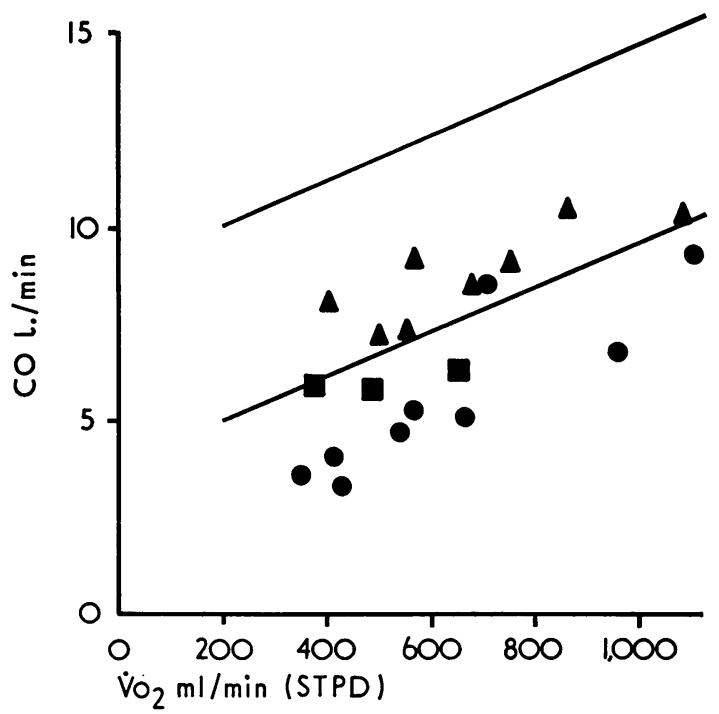

FIG. I Cardiac output and oxygen uptake during exercise in primary or thromboembolic pulmonary hypertension (circles), residual postoperative pulmonary hypertension (squares), and pulmonary hypertension secondary to obstructive lung disease (triangles). The normal limits of the relation of the two parameters, obtained from Gazetopoulos et al. (I966b), are shown.

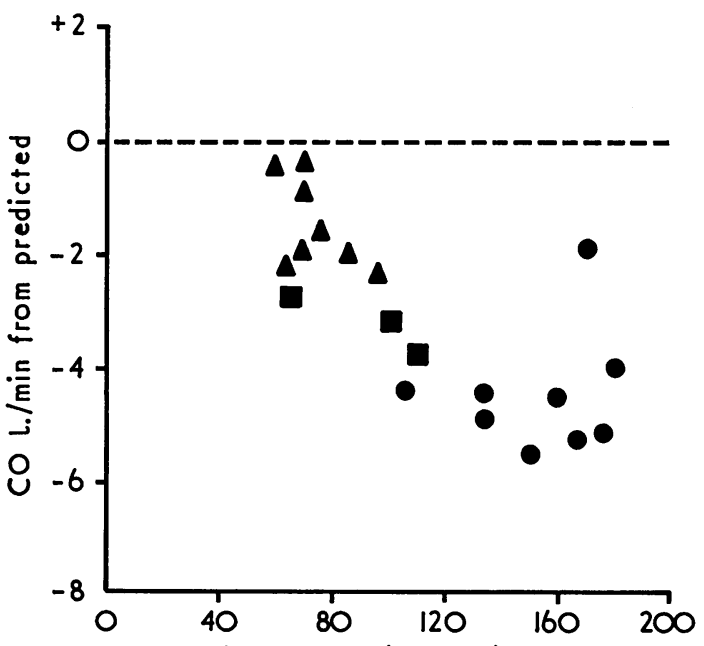

PA systolic pressure $(\mathrm{mm} \mathrm{Hg})$

FIG. 2 Exercise cardiac output expressed as a deviation from the mean predicted normal, in relation to pulmonary arterial systolic pressure. Symbols as in Fig. $I$.

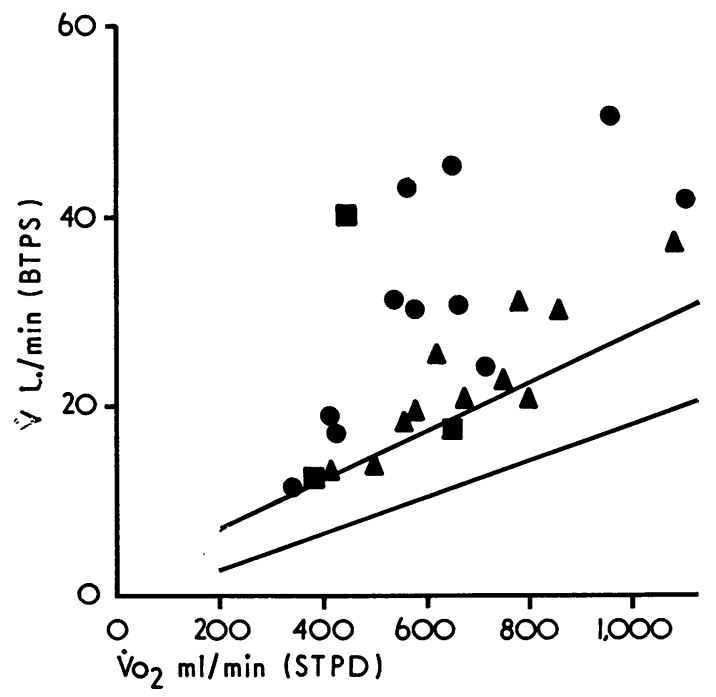

FIG. 3 Ventilation and oxygen uptake during exercise. The normal limits of the relation of the two parameters, obtained from Gazetopoulos et al., (I966b), are shown. Symbols as in Fig. I.

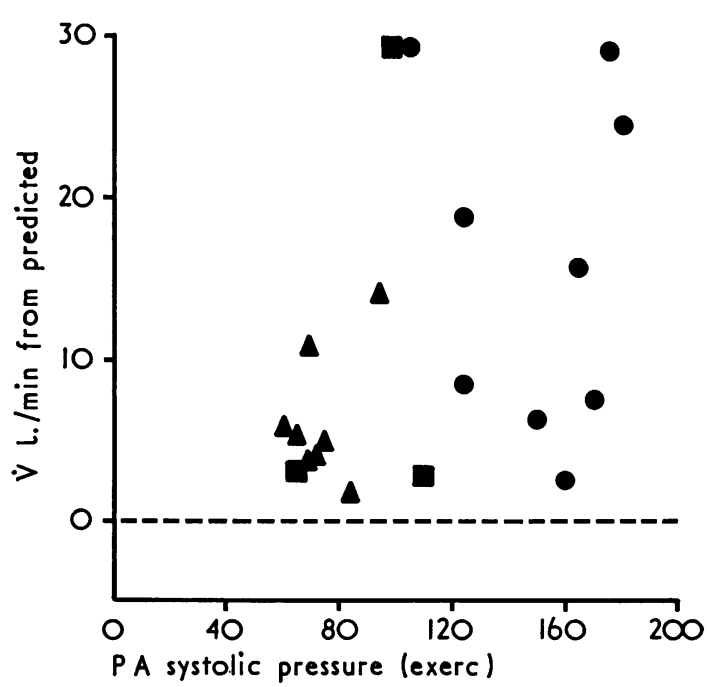

FIG. 4 Exercise ventilation, expressed as a deviation from the mean predicted normal, in relation to pulmonary arterial systolic pressure. Symbols as in Fig. $I$. 


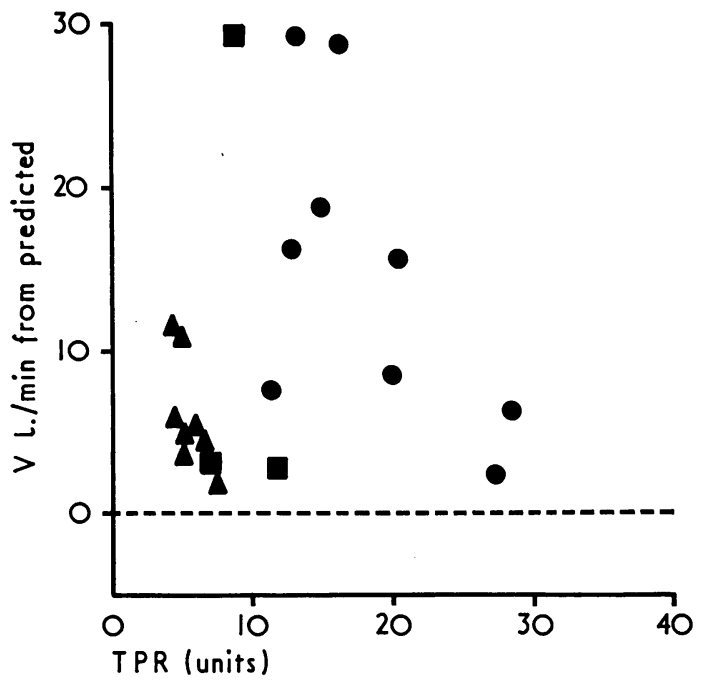

FIG. 5 Excess exercise ventilation in relation to total pulmonary vascular resistance. Symbols as in Fig. $I$.

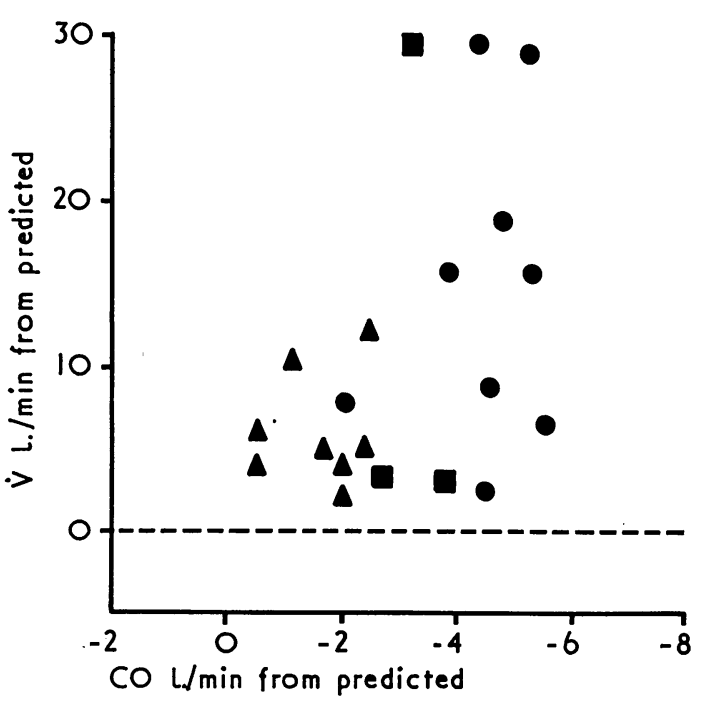

FIG. 6 The relation between excess ventilation and degree of impairment of cardiac output during exercise, both expressed as a deviation from the mean predicted normal. Symbols as in Fig. $r$.

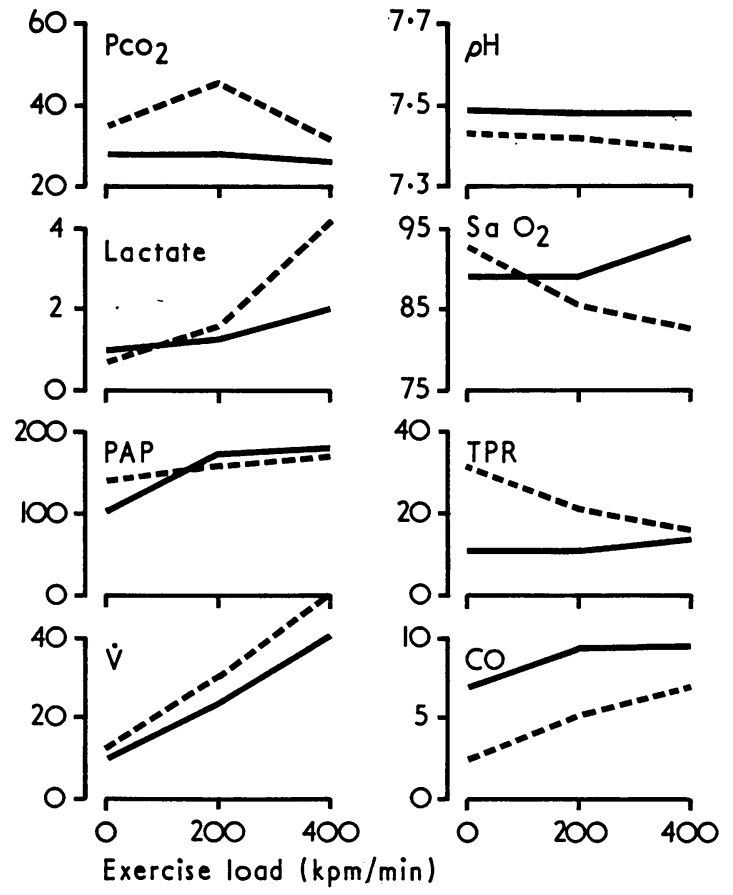

FIG. 7 Ventilation ( $\dot{V})$, cardiac output $(C O)$, systolic pulmonary arterial pressure $(P A P)$, total pulmonary vascular resistance (TPR), and arterial blood composition at rest and during stepwise increasing exercise in the two studies performed in Case 2. The time interval between the first (solid line) and the second study (broken line) is 3 years.

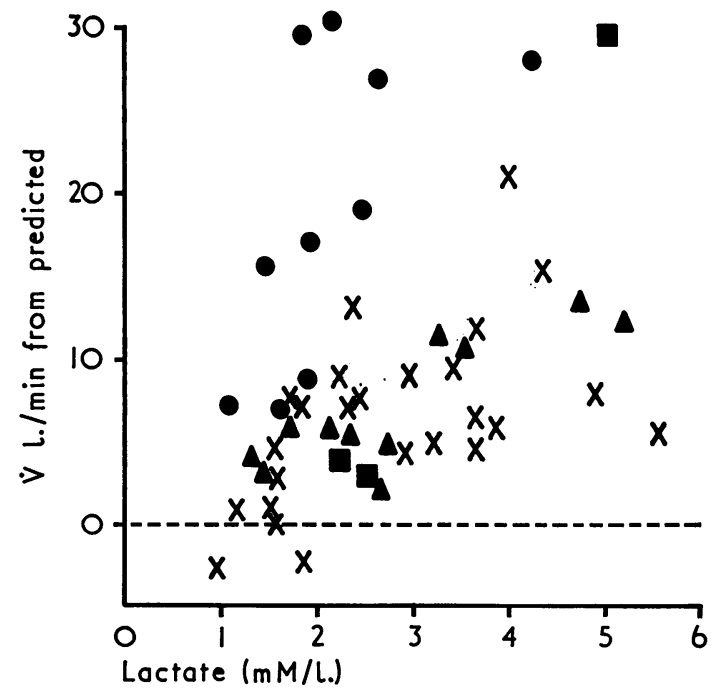

FIG. 8 Excess ventilation in relation to lactate concentration during exercise. The findings in patients with isolated pulmonary stenosis (X), obtained from Gazetopoulos et al. (I966a), are shown. Otherwise symbols as in Fig. I. (For discussion see text.) 
of conditions of different aetiology, clinical picture, and course. The coexistence of several interacting disturbances in most of these conditions often makes it difficult to evaluate the effects of pulmonary hypertension on circulatory and ventilatory function. A comparative study of the various forms of pulmonary hypertension would probably lead to a better understanding of the functional significance

TABLE 3 Ventilatory data, haemodynamic data, and arterial blood composition

\begin{tabular}{|c|c|c|c|c|c|c|c|c|c|c|c|}
\hline \multirow{4}{*}{$\begin{array}{l}\text { Case } \\
\text { No. } \\
\text { I }\end{array}$} & \multirow{2}{*}{\multicolumn{2}{|c|}{$\begin{array}{l}\text { Exercise } \\
\text { load } \\
(\mathrm{kpm} / \mathrm{min})\end{array}$}} & \multirow{3}{*}{$\begin{array}{l}\begin{array}{l}\dot{V} \mathrm{O}_{2}{ }^{\star} \\
(\mathrm{ml} / \mathrm{min})\end{array} \\
S T P D\end{array}$} & \multirow{3}{*}{$\begin{array}{c}\begin{array}{l}\text { Heart } \\
\text { rate }\end{array} \\
76\end{array}$} & \multirow{3}{*}{$\begin{array}{l}\begin{array}{l}\text { Cardiac } \\
\text { output } \\
(l . / m i n)\end{array} \\
3 \cdot 7\end{array}$} & \multirow{3}{*}{$\begin{array}{l}\begin{array}{l}\text { Resp. } \\
\text { rate }\end{array} \\
15\end{array}$} & \multirow{3}{*}{$\begin{array}{l}\dot{\dot{V}} \\
\begin{array}{l}(l . / \min ) \\
B T P S\end{array} \\
9.6\end{array}$} & \multirow{3}{*}{$\frac{{ }_{\text {mean }}^{P C V^{\star} \dagger}}{7}$} & \multicolumn{3}{|c|}{ Pressures $(\mathrm{mmHg})$} \\
\hline & & & & & & & & & \multirow{2}{*}{$\begin{array}{l}\text { Pulm. art. } \\
\text { s/d/m } \\
90 / 50 / 66\end{array}$} & \multirow{2}{*}{$\begin{array}{l}\begin{array}{l}R . \text { vent. } \\
\text { s/d }\end{array} \\
92 / \mathrm{I} \mathrm{I}\end{array}$} & \multirow{2}{*}{$\begin{array}{l}\text { Syst. art. } \\
\text { s/d/m } \\
\mathrm{I} 10 / 70 / 85\end{array}$} \\
\hline & $\mathbf{R}$ & ० & & & & & & & & & \\
\hline & $\mathbf{E}$ & 200 & 565 & 125 & $5 \cdot 2$ & 32 & $42 \cdot 3$ & - & $105 / 55 / 70$ & $105 / 10$ & - \\
\hline \multirow[t]{3}{*}{$2 a$} & $\mathbf{R}$ & 0 & 330 & 75 & $6 \cdot 8$ & 13 & 10.5 & 7 & $100 / 50 / 75$ & $100 / 10$ & $165 / 95 / 110$ \\
\hline & $\mathrm{E}$ & 200 & 715 & 100 & $8 \cdot 4$ & 25 & $23 \cdot 8$ & - & $170 / 65 / 95$ & 一 & $190 / 105 / 130$ \\
\hline & $\mathbf{E}$ & 400 & 1100 & 130 & $9 \cdot I$ & - & $40 \cdot 7$ & - & $180 / 80 / 120$ & 一 & $195 / 120 / 135$ \\
\hline \multirow[t]{3}{*}{$2 b$} & $\mathbf{R}$ & 0 & 260 & 90 & $2 \cdot 9$ & 18 & 10.7 & Io & $140 / 60 / 90$ & $140 / 15$ & $125 / 90 / 105$ \\
\hline & $\mathbf{E}$ & 200 & 665 & I10 & 4.9 & 27 & 30.5 & 12 & $165 / 60 / 100$ & $165 / 25$ & $140 / 95 / 110$ \\
\hline & $\mathbf{E}$ & 400 & 960 & 155 & $6 \cdot 8$ & 34 & $49 \cdot 5$ & - & $175 / 60 / 110$ & - & - \\
\hline \multirow[t]{2}{*}{3} & $\mathbf{R}$ & 0 & 220 & 80 & $3 \cdot 2$ & 23 & 13.5 & 8 & $110 / 45 / 60$ & $110 / 13$ & $80 / 60 / 70$ \\
\hline & $\mathbf{E}$ & 200 & 650 & 128 & - & 32 & $44 \cdot 9$ & - & - & - & - \\
\hline \multirow[t]{2}{*}{4} & $\mathbf{R}$ & 0 & 230 & IIO & $3 \cdot 5$ & 23 & 8.8 & Io & $120 / 50 / 75$ & $125 / 16$ & $155 / 105 / 135$ \\
\hline & $\mathbf{E}$ & 100 & 415 & 125 & 4.0 & 28 & 18.5 & - & $125 / 50 / 80$ & - & $180 / 130 / 145$ \\
\hline \multirow[t]{2}{*}{5} & $\mathbf{R}$ & 0 & 140 & 58 & $2 \cdot 4$ & 22 & $9 \cdot 7$ & 5 & $105 / 25 / 55$ & $105 / 10$ & $100 / 50 / 65$ \\
\hline & $\mathrm{E}$ & 100 & 540 & 80 & $4 \cdot 6$ & 30 & $31 \cdot 0$ & 3 & $125 / 30 / 70$ & $125 / 12$ & II $5 / 60 / 75$ \\
\hline 6 & $\mathbf{R}$ & 0 & 200 & 75 & $2 \cdot 4$ & 16 & $6 \cdot 8$ & - & $125 / 50 / 75$ & $125 / 10$ & $95 / 60 / 70$ \\
\hline & $\mathbf{E}$ & 100 & 430 & 100 & $3 \cdot 2$ & 20 & 16.8 & - & $150 / 60 / 90$ & - & $110 / 60 / 75$ \\
\hline 7 & $\overline{\mathbf{R}}$ & 0 & 170 & 76 & 2.9 & 17 & 4.7 & 5 & $100 / 40 / 60$ & $100 / 4$ & $115 / 75 / 85$ \\
\hline & $\mathbf{E}$ & 100 & 345 & IIo & $3 \cdot 6$ & 20 & II O & 7 & $160 / 70 / 100$ & - & - \\
\hline 8 & $\mathbf{R}$ & 0 & 185 & 90 & - & 16 & 10.5 & - & - & - & - \\
\hline & $\mathbf{E}$ & 200 & 580 & 120 & - & 26 & $30 \cdot 2$ & - & - & - & - \\
\hline 9 & $\mathbf{R}$ & 0 & 220 & 76 & $4 \cdot 3$ & 15 & 6.6 & - & $110 / 60 / 75$ & I Io/10 & I Io/65/80 \\
\hline & $\mathbf{E}$ & 一 & - & - & - & - & - & - & - & - & - \\
\hline I0 & $\mathbf{R}$ & 0 & 250 & 108 & $5 \cdot 1$ & 13 & $8 \cdot 6$ & 16 & $70 / 35 / 45$ & $70 / 12$ & $155 / 85 / 100$ \\
\hline & $\mathbf{E}$ & 100 & 450 & 136 & $7 \cdot 1$ & 36 & $40 \cdot 0$ & 21 & $100 / 42 / 50$ & - & $155 / 85 / 95$ \\
\hline II & $\mathbf{R}$ & 0 & 230 & 65 & $4 \cdot 2$ & 15 & 5.0 & 9 & $75 / 35 / 55$ & $72 / 7$ & $130 / 65 / 70$ \\
\hline & E & 200 & 650 & 120 & $6 \cdot 2$ & 20 & $17 \cdot 6$ & 12 & I $10 / 65 / 75$ & I10/10 & $150 / 85 / 95$ \\
\hline 12 & $\mathbf{R}$ & 0 & 200 & 80 & $4 \cdot 8$ & 20 & $7 \cdot 0$ & 10 & $60 / 20 / 35$ & $65 / 7$ & $125 / 70 / 90$ \\
\hline & $\mathrm{E}$ & 100 & 380 & 94 & $5 \cdot 8$ & 28 & $12 \cdot 3$ & II & $65 / 28 / 40$ & $68 / 6$ & $128 / 75 / 95$ \\
\hline 13 & $\mathbf{R}$ & 0 & 290 & 90 & $7 \cdot 4$ & 15 & $9 \cdot 9$ & 10 & $45 / 30 / 34$ & $45 / 8$ & $135 / 90 / 120$ \\
\hline & $\mathbf{E}$ & 200 & 860 & 140 & $10 \cdot 3$ & - & $29 \cdot 7$ & - & $70 / 25 / 50$ & $70 / 12$ & $160 / 100 / 120$ \\
\hline 14 & $\mathbf{R}$ & 0 & 210 & 64 & $3 \cdot 7$ & 16 & $8 \cdot 8$ & 16 & $50 / 25 / 35$ & $50 / 8$ & $180 / 110 / 130$ \\
\hline & $\mathrm{E}$ & 200 & 750 & 88 & $9 \cdot 0$ & 22 & $22 \cdot 0$ & 22 & $75 / 45 / 50$ & - & $220 / 120 / 170$ \\
\hline 15 & $\overline{\mathbf{R}}$ & 0 & 310 & 96 & $8 \cdot 8$ & 16 & $8 \cdot 7$ & II & $40 / 22 / 28$ & $38 / 12$ & - \\
\hline & $\mathrm{E}$ & 300 & 800 & 120 & - & 21 & $20 \cdot 4$ & - & - & - & - \\
\hline 16 & $\mathbf{R}$ & 0 & 185 & 76 & $6 \cdot 4$ & I8 & $6 \cdot 2$ & 7 & $40 / 25 / 32$ & $40 / 6$ & $95 / 55 / 70$ \\
\hline & E & 200 & 560 & 104 & $7 \cdot 2$ & - & $17 \cdot 8$ & 8 & $65 / 30 / 40$ & $65 / 5$ & $115 / 60 / 75$ \\
\hline 17 & $\mathbf{R}$ & o & 220 & 80 & $7 \cdot 0$ & I4 & $8 \cdot 4$ & 10 & $55 / 30 / 35$ & $55 / 8$ & $165 / 85 / 100$ \\
\hline & $\mathbf{E}$ & 200 & 680 & 96 & $8 \cdot 4$ & 28 & $20 \cdot 2$ & - & $72 / 30 / 40$ & - & $170 / 85 / 100$ \\
\hline & $\mathbf{E}$ & 400 & 1080 & 145 & $10 \cdot 2$ & 34 & $35 \cdot 8$ & 一 & $95 / 35 / 50$ & - & - \\
\hline 18 & $\mathbf{R}$ & 0 & 215 & 94 & $9 \cdot 7$ & 22 & $7 \cdot 0$ & 8 & $50 / 20 / 30$ & $50 / 5$ & $130 / 80 / 95$ \\
\hline & $\mathbf{E}$ & 200 & 405 & 107 & $8 \cdot I$ & 27 & $13 \cdot 0$ & 13 & $70 / 30 / 45$ & $70 / 8$ & $150 / 80 / 100$ \\
\hline 19 & $\overline{\mathbf{R}}$ & 0 & 210 & 95 & $5 \cdot 6$ & 24 & $7 \cdot 7$ & 7 & $40 / 23 / 27$ & $35 / 7$ & $110 / 80 / 85$ \\
\hline & $\mathbf{E}$ & 200 & 575 & 130 & $9 \cdot I$ & $4 I$ & $19 \cdot 1$ & - & $60 / 37 / 44$ & - & I $10 / 70 / 82$ \\
\hline 20 & $\mathbf{R}$ & 0 & 130 & 64 & $3 \cdot 2$ & 13 & $4 \cdot 7$ & Io & $70 / 30 / 40$ & $68 / 4$ & $100 / 60 / 75$ \\
\hline & $\mathbf{E}$ & 100 & 500 & 100 & $7 \cdot 1$ & 24 & 13.6 & - & $85 / 40 / 55$ & $90 / 8$ & $100 / 65 / 75$ \\
\hline $2 \mathbf{I}$ & $\mathbf{R}$ & 0 & 225 & 84 & $9 \cdot 3$ & - & $8 \cdot 0$ & - & $50 / 20 / 30$ & $50 / 8$ & $100 / 50 / 65$ \\
\hline & $\mathbf{E}$ & 300 & 780 & 120 & - & 一 & 30.5 & - & - & - & - \\
\hline 22 & $\mathbf{R}$ & 0 & 250 & 72 & $4 \cdot 8$ & 16 & $9 \cdot 3$ & 8 & $58 / 20 / 30$ & $55 / 4$ & $140 / 80 / 90$ \\
\hline & $\mathbf{E}$ & 200 & 620 & 138 & - & 26 & $25 \cdot 1$ & - & _ & & 工 \\
\hline 23 & $\mathbf{R}$ & 0 & 210 & 78 & $6 \cdot 7$ & 24 & $7 \cdot 0$ & - & $100 / 65 / 80$ & $100 / 35$ & $130 / 75 / 90$ \\
\hline & $\mathbf{E}$ & - & - & - & - & 一 & - & - & - & - & - \\
\hline
\end{tabular}

$\star \dot{\mathrm{V}} \mathrm{O}_{2}=$ oxygen uptake.

$\dot{\mathrm{V}}=$ ventilation minute volume.

$+\mathrm{PCV}=$ pulmonary capillary venous (wedge).

$\ddagger \mathrm{s} / \mathrm{d} / \mathrm{m}=$ systolic, diastolic, mean.

STPD = standard temperature, pressure dry; BTPS = body temperature, pressure saturated with water vapour.

$\mathrm{R}$, rest; $\mathrm{E}$, exercise; $\mathrm{SO}_{2}=$ arterial oxygen saturation; $\mathrm{PCO}_{2}=$ arterial partial pressure of $\mathrm{Co}_{2}$. 
of increased pulmonary arterial pressure and of the role of coexisting anomalies. Table 4 shows the usual findings in the different situations where increased pulmonary arterial pressure is present.

TABLE 3 (Cont'd)

\begin{tabular}{|c|c|c|c|c|}
\hline \multicolumn{5}{|c|}{ Arterial blood } \\
\hline $\begin{array}{l}\mathrm{So}_{2} \\
\%\end{array}$ & $\begin{array}{l}\mathrm{Pco}_{2} \\
(\mathrm{mmHg})\end{array}$ & $\mathrm{p} H$ & $\begin{array}{l}\text { Lactate } \\
(m M / l .)\end{array}$ & $\begin{array}{l}\text { Pyruvate } \\
(\mathrm{mM} / \mathrm{l} .)\end{array}$ \\
\hline 87.7 & $20 \cdot 6$ & $7 \cdot 47$ & 0.57 & 0.07 \\
\hline $87 \cdot 3$ & $21 \cdot 9$ & $7 \cdot 46$ & 1.80 & $0.1 I$ \\
\hline 88.8 & $28 \cdot 3$ & $7 \cdot 49$ & $1 \cdot 00$ & 0.06 \\
\hline $88 \cdot 8$ & $28 \cdot 3$ & $7 \cdot 48$ & I. 10 & 0.09 \\
\hline $93 \cdot 2$ & $26 \cdot 3$ & $7 \cdot 48$ & $1 \cdot 95$ & 0.12 \\
\hline $92 \cdot 3$ & $36 \cdot 0$ & 7.43 & 0.90 & 0.07 \\
\hline $85 \cdot 3$ & $45 \cdot 0$ & $7 \cdot 41$ & $I \cdot 45$ & 0.10 \\
\hline $82 \cdot 0$ & $32 \cdot 0$ & $7 \cdot 39$ & 4.25 & 0.18 \\
\hline $87 \cdot 5$ & $24 \cdot 8$ & $7 \cdot 58$ & 0.76 & - \\
\hline $90 \cdot 5$ & - & - & $2 \cdot 17$ & - \\
\hline $80 \cdot 0$ & $31 \cdot 5$ & $7 \cdot 37$ & $I \cdot 23$ & 0.14 \\
\hline $83 \cdot 8$ & $32 \cdot 5$ & $7 \cdot 36$ & $1 \cdot 89$ & 0.22 \\
\hline $85 \cdot 7$ & $31 \cdot 0$ & $7 \cdot 46$ & 0.59 & 0.08 \\
\hline 83.0 & 30.5 & $7 \cdot 46$ & $2 \cdot 47$ & 0.14 \\
\hline 89.7 & $36 \cdot 0$ & $7 \cdot 42$ & 0.91 & 0.08 \\
\hline $91 \cdot 5$ & $35 \cdot 6$ & $7 \cdot 41$ & $1 \cdot 62$ & 0.09 \\
\hline $96 \cdot 0$ & - & - & - & - \\
\hline $96 \cdot 0$ & - & - & - & - \\
\hline $98 \cdot 0$ & $37 \cdot 0$ & $7 \cdot 52$ & $\mathbf{I} \cdot \mathbf{I} \mathbf{I}$ & 0.06 \\
\hline $96 \cdot 0$ & $30 \cdot 0$ & 7.51 & $2 \cdot 73$ & - \\
\hline $89 \cdot 0$ & - & - & - & - \\
\hline- & - & - & - & - \\
\hline $93 \cdot 0$ & $32 \cdot 5$ & $7 \cdot 48$ & 0.72 & 0.08 \\
\hline 84.5 & 30.0 & $7 \cdot 44$ & 5.00 & 0.24 \\
\hline $93 \cdot 2$ & $43 \cdot 0$ & $7 \cdot 35$ & I. IO & 0.13 \\
\hline $96 \cdot 7$ & $37 \cdot 0$ & $7 \cdot 35$ & 2.50 & 0.19 \\
\hline $97 \cdot 8$ & 40.5 & $7 \cdot 42$ & $\mathbf{I} \cdot \mathbf{I I}$ & 0.11 \\
\hline $97 \cdot 6$ & $38 \cdot 0$ & $7 \cdot 41$ & $2 \cdot 15$ & 0.16 \\
\hline 84.5 & $36 \cdot 8$ & $7 \cdot 49$ & 0.85 & 0.04 \\
\hline 94.0 & $34 \cdot 8$ & $7 \cdot 47$ & 3.58 & 0.09 \\
\hline $90 \cdot 5$ & $43 \cdot 0$ & $7 \cdot 40$ & 0.82 & - \\
\hline 89.0 & - & $7 \cdot 34$ & $2 \cdot 34$ & - \\
\hline 84.7 & $39 \cdot 3$ & $7 \cdot 45$ & $\mathrm{I} \cdot 02$ & - \\
\hline 89.5 & $40 \cdot 8$ & $7 \cdot 4 \mathrm{I}$ & $I \cdot 46$ & - \\
\hline $90 \cdot 2$ & $43 \cdot 2$ & $7 \cdot 40$ & 0.72 & 0.08 \\
\hline $88 \cdot 0$ & $44 \cdot 0$ & $7 \cdot 38$ & $2 \cdot 30$ & 0.12 \\
\hline $90 \cdot 0$ & $48 \cdot 0$ & $7 \cdot 38$ & 0.82 & 0.07 \\
\hline 90.5 & $51 \cdot 5$ & $7 \cdot 35$ & $2 \cdot 75$ & 0.13 \\
\hline $93 \cdot 2$ & $47 \cdot 2$ & $7 \cdot 30$ & $5 \cdot 21$ & 0.18 \\
\hline 86.0 & $60 \cdot 0$ & $7 \cdot 42$ & 0.91 & 0.05 \\
\hline $85 \cdot 2$ & $50 \cdot 0$ & $7 \cdot 40$ & $I \cdot 30$ & 0.11 \\
\hline 89.6 & $40 \cdot 0$ & $7 \cdot 41$ & 0.84 & 0.08 \\
\hline $82 \cdot 4$ & $44 \cdot 0$ & $7 \cdot 39$ & 1.69 & 0.14 \\
\hline $75 \cdot 8$ & $6 \mathrm{r} \cdot 0$ & $7 \cdot 33$ & 0.97 & 0.04 \\
\hline $66 \cdot 1$ & 65.0 & $7 \cdot 3 I$ & $2 \cdot 60$ & 0.07 \\
\hline $80 \cdot 0$ & $40 \cdot 0$ & $7 \cdot 46$ & 0.91 & 0.10 \\
\hline 87.0 & $42 \cdot 0$ & $7 \cdot 35$ & $4 \cdot 76$ & 0.19 \\
\hline 86.0 & $60 \cdot 2$ & $7 \cdot 39$ & $\mathrm{I} \cdot 16$ & - \\
\hline $82 \cdot 8$ & 56.0 & $7 \cdot 35$ & 3.25 & 一 \\
\hline $56 \cdot 0$ & $76 \cdot 0$ & $7 \cdot 38$ & - & - \\
\hline- & - & - & - & 一 \\
\hline
\end{tabular}

In agreement with many others (McIlroy and Apthorp, 1958; Kitchin, Lowther, and Matthews, 196r, Wessel, Kezdi, and Cugell, 1964; Shaw et al., 1965), we have found that the cardiac output is reduced, especially during exercise in primary and thromboembolic pulmonary hypertension, and that it is usually in the low-normal range in pulmonary hypertension due to obstructive lung disease (Fig. I). Usually, the higher the pulmonary arterial pressure in both these situations, the lower the cardiac output (Fig. 2).

Similar findings were observed in pulmonary hypertension secondary to left heart disease (Gazetopoulos et al., 1966b) and in relation to the systemic blood flow in hyperkinetic pulmonary hypertension (Davies and Gazetopoulos, 1966b). The few existing haemodynamic data in patients with pulmonary interstitial fibrosis (Wade and Bishop, 1962; Sackner et al., 1964) and residual postoperative pulmonary hypertension (Fig. 2), also suggest a similar circulatory disturbance. In the Eisenmenger syndrome, systemic hypertension is in most cases obligatory and the effective pulmonary flow is not as closely related to the level of pulmonary arterial pressure, though it is low.

Pulmonary hypertension is thus associated with reduced cardiac output, particularly on effort, but exceptions occur as is seen in the first study of our Case 2 and probably in residents at high altitude (Penaloza et al., 1963). Other factors, such as the presence of atrial fibrillation and myocardial fibrosis may contribute to the low output. On the other hand, hypoxaemia is likely to have an opposite effect (Shaw et al., 1965).

The effect of pulmonary hypertension on the function of the lungs is variable, and depends on the underlying condition (Table 4). In primary and thromboembolic pulmonary hypertension, routine pulmonary function tests show virtually normal values, and compliance is normal or slightly impaired (McIlroy and Apthorp, 1958; Wessel et al., 1964; Jones and Goodwin, 1965; Storstein et al., 1966; and Table 2). Only more sophisticated measurements, such as the distribution of ventilation and perfusion, indicate how gross the disturbance of lung function may sometimes be (Bass, Heckscher, and Anthonisen, 1967). In left heart disease with pulmonary venous hypertension (Donald, 1959), the lungs are stiff as a result of vascular engorgement and perivascular oedema and fibrosis. Airway resistance is normal or slightly increased. Ventilationperfusion abnormalities may occur, particularly in the more chronic situations such as mitral stenosis. In left-to-right shunts with hyperkinetic pulmonary hypertension the lung compliance is reduced but other aspects of lung function remain near normal 
(Davies, Williams, and Wood, I962; Woolf, I963; Davies and Gazetopoulos, 1967). Virtually normal lung function is also seen in the Eisenmenger syndromes (McIlroy and Apthorp, 1958; Davies and Gazetopoulos, 1967), in pulmonary hypertension of high altitude (Hurtado, I964), and in residual postoperative pulmonary hypertension. Some degree of arterial desaturation, due largely to ventilationperfusion inequality, is commonly seen in patients with pulmonary hypertension of any cause, but is not an invariable finding.

It is clear that pulmonary hypertension per se has no uniform effect on lung function or arterial blood composition; though the physiological disturbance may be considerable, this depends on the nature of the associated disease.

Exercise hyperventilation is usually present in most groups of patients with pulmonary hypertension. Our data and other studies indicate that pulmonary arterial pressure cannot be the determining factor for excessive ventilatory response; they also show that in the majority of cases there are no chemical changes which would act as a ventilatory drive (Cotes, 1955; McIlroy and Apthorp, 1958; Turino et al., 1963; Sloman and Gandevia, 1964; Wessel et al., 1964; Gazetopoulos et al., 1966a, b).

It has been suggested (McIlroy, 1959) that a major cause of hyperventilation in heart disease is low cardiac output, operating through the medium of tissue hypoxia and lactic acidaemia. Furthermore, a relation between tissue hypoxia, as evidenced by lactate production, and the degree of exercise hyperventilation, has been demonstrated in some low output situations, such as isolated pulmonary stenosis, where the lungs are normal and other respiratory stimuli are not present (Gazetopoulos et al., 1966a). The existence of a similar mechanism determining hyperventilation in primary and thromboembolic pulmonary hypertension appears to be supported by Case 2 where the progress of the disease was associated with further reduction in cardiac output, increased lactic acidaemia, and increased ventilation (Fig. 7). However, ventilation increased disproportionately to the degree of lactic acidaemia in this case, when compared with cases of pulmonary stenosis. Furthermore, other patients with primary or thromboembolic pulmonary hypertension who showed similar degrees of exercise hyperventilation had low lactate levels (Fig. 8). This suggests strongly that factors other than tissue hypoxia are playing an important role in the determination of exercise ventilation in these patients.

In mitral valve and left heart disease, we showed that exercise hyperventilation is also disproportionate to the lactate levels, and is related mainly to the increase in left atrial pressure (Gazetopoulos et al., I966b). In left-to-right shunts with hyperkinetic pulmonary hypertension pronounced hyperventilation does not usually occur, except when pulmonary venous hypertension is present (Gazetopoulos and Davies, 1966). In the Eisenmenger syndromes, as in other varieties of severe cyanotic congenital heart

TABLE 4 Usual pathophysiological findings in various forms of pulmonary hypertension

\begin{tabular}{|c|c|c|c|c|c|c|c|c|}
\hline Form & $\begin{array}{l}\text { Pulmonary } \\
\text { flow }\end{array}$ & $\begin{array}{l}\text { Systemic } \\
\text { flow }\end{array}$ & $\begin{array}{l}\text { Airway } \\
\text { resistance }\end{array}$ & $\begin{array}{l}\text { Lung } \\
\text { compliance }\end{array}$ & $\begin{array}{l}\text { Lung } \\
\text { diffusion }\end{array}$ & $\begin{array}{l}\text { Arterial } \\
\text { oxygenation }\end{array}$ & $\begin{array}{l}\text { Exercise } \\
\text { ventilation }\end{array}$ & $\begin{array}{l}\text { Exercise } \\
\text { tolerance }\end{array}$ \\
\hline $\begin{array}{l}\text { Pulmonary } \\
\text { venous } \\
\text { hypertension }\end{array}$ & Low & Low & $\begin{array}{l}\text { Little } \\
\text { in- } \\
\text { creased }\end{array}$ & Low & $\begin{array}{l}\text { Normal or } \\
\text { decreased }\end{array}$ & $\begin{array}{l}\text { Normal or } \\
\text { little } \\
\text { decreased }\end{array}$ & High & Low \\
\hline $\begin{array}{l}\text { Hyperkinetic } \\
\text { pulmonary } \\
\text { hypertension }\end{array}$ & High & Low & Normal & Low & $\begin{array}{l}\text { Normal or } \\
\text { little } \\
\text { increased }\end{array}$ & $\begin{array}{l}\text { Normal or } \\
\text { little } \\
\text { decreased }\end{array}$ & $\begin{array}{l}\text { Normal or } \\
\text { little } \\
\text { increased }\end{array}$ & $\begin{array}{l}\text { Little } \\
\quad \text { decreased }\end{array}$ \\
\hline $\begin{array}{l}\text { Eisenmenger } \\
\text { syndromes }\end{array}$ & Low & Normal & Normal & Normal & Normal & Low & High & Low \\
\hline $\begin{array}{l}\text { Primary or } \\
\text { thrombo- } \\
\text { embolic } \\
\text { pulmonary } \\
\text { hypertension }\end{array}$ & Low & Low & Normal & Normal & $\begin{array}{l}\text { Normal or } \\
\text { decreased }\end{array}$ & $\begin{array}{l}\text { Normal or } \\
\text { little } \\
\text { decreased }\end{array}$ & High & Low \\
\hline $\begin{array}{l}\text { Obstructive } \\
\text { lung disease }\end{array}$ & $\begin{array}{l}\text { Normal or } \\
\text { little } \\
\text { decreased }\end{array}$ & $\begin{array}{l}\text { Normal or } \\
\text { little } \\
\text { decreased }\end{array}$ & High & $\begin{array}{l}\text { Normal or } \\
\text { little } \\
\text { decreased }\end{array}$ & $\begin{array}{l}\text { Normal or } \\
\text { decreased }\end{array}$ & $\begin{array}{l}\text { Normal or } \\
\text { little } \\
\text { decreased }\end{array}$ & $\begin{array}{l}\text { Normal or } \\
\text { little } \\
\text { increased }\end{array}$ & Low \\
\hline $\begin{array}{l}\text { Pulmonary } \\
\text { interstitial } \\
\text { fibrosis }\end{array}$ & $\begin{array}{l}\text { Little } \\
\quad \text { decreased }\end{array}$ & $\begin{array}{l}\text { Little } \\
\quad \text { decreased }\end{array}$ & Normal & Low & Low & Decreased & High & Low \\
\hline $\begin{array}{l}\text { Pulmonary } \\
\text { hypertension } \\
\text { of high } \\
\text { altitude }\end{array}$ & Normal & Normal & Normal & Normal & $\begin{array}{l}\text { Normal or } \\
\text { increased }\end{array}$ & $\begin{array}{l}\text { Normal or } \\
\text { little } \\
\text { decreased }\end{array}$ & $\begin{array}{l}\text { Normal or } \\
\text { little } \\
\text { increased }\end{array}$ & Normal \\
\hline
\end{tabular}


disease, arterial blood gases are an important determinant of hyperventilation (Davies and Gazetopoulos, I965). The observation that patients with persistent ductus and the 'Eisenmenger syndrome', in whom the venous blood bypasses the carotid and brain chemoreceptors, do not hyperventilate significantly, indicates the absence of other powerful respiratory stimuli in the Eisenmenger syndromes (Gazetopoulos et al., 1972).

In cor pulmonale due to obstructive lung disease, hyperventilation is not pronounced and is of a degree that would be expected to occur as a result of tissue hypoxia, with a mechanism similar to pulmonary stenosis (Fig. 8). The same mechanism is also likely to determine the ventilatory response in the majority of patients with hyperkinetic pulmonary hypertension (Gazetopoulos and Davies, 1966), in patients with 'Eisenmenger ductus' (Gazetopoulos et al., 1972), and possibly in residual postoperative pulmonary hypertension, as well as in pulmonary hypertension due to high altitude.

The fact that patients with primary or thromboembolic hypertension hyperventilate much more than those with pulmonary stenosis or obstructive lung disease, with similar lactate levels, leads to the conclusion that a low cardiac output with consequent tissue hypoxia is not an important cause of hyperventilation in this group. This brings back the focus of attention from the periphery to the lungs themselves.

It is true that in patients with primary and thromboembolic pulmonary hypertension the pulmonary blood flow is grossly limited and many ventilated alveoli receive no perfusion. It would be reasonable to assume that, in order to cover the oxygen needs of the body, every means available should be used to increase oxygen transport in the lungs by raising the $\mathrm{PO}_{2}$ in the perfused alveoli; it is possible that the observed gross effort hyperventilation is related to this requirement.

However, because of the adaptability in chronic hypoxaemia (Severinghaus, Bainton, and Carcelen, 1966; Edelman et al., 1968) and since other forms of heart disease associated with low alveolar perfusion show no pronounced hyperventilation, one must come to the conclusion that ventilation in these patients is driven by abnormal receptor impulses from the lungs and pulmonary vessels. There is some evidence that such impulses do exist (Guz et al., 1970) though their exact mechanism remains to be elucidated.

Cases studied at Guy's Hospital were under the care of the late Dr. C. G. Baker and of Dr. D. C. Deuchar to whom we are indebted.

\section{References}

Bass, H., Heckscher, T., and Anthonisen, N. R. (1967).
Regional pulmonary gas exchange in patients with pulmonary embolism. Clinical Science, 33, 355.

Bates, D. V. (1952). The uptake of carbon monoxide in health and in emphysema. Clinical Science, 11, 21.

Bates, D. V., Macklem, P. T., and Christie, R. V. (1971). Respiratory Function in Disease, 2nd ed. W. B. Saunders, London.

Comroe, J. H., Jr., and Fowler, W. S. (195I). Lung function studies. VI. Detection of uneven alveolar ventilation during a single breath of oxygen. American fournal of Medicine, ro, 408.

Cotes, J. E. (1955). The role of oxygen, carbon dioxide and lactic acid in the ventilatory response to exercise in patients with mitral stenosis. Clinical Science, 14, 317.

Davies, H., and Gazetopoulos, N. (1965). Dyspnoea in cyanotic congenital heart disease. British Heart fournal, 27, 28.

Davies, D. H., and Gazetopoulos, N. (1966a). Dyspnoea and differential hypercapnia in the Eisenmenger ductus. Guy's Hospital Reports, 115, 175.

Davies, H., and Gazetopoulos, N. (1966b). Haemodynamic changes on exercise in patients with left-to-right shunts. British Heart fournal, 28, 579.

Davies, H., and Gazetopoulos, N. (1967). Lung function in patients with left-to-right shunts. British Heart fournal, 29, 317.

Davies, H., Gazetopoulos, N., and Oliver, C. (1965). Ventilatory and metabolic response to graduated and prolonged exercise in normal subjects. Clinical Science, 29, 443.

Davies, H., Williams, J., and Wood, P. (1962). Lung stiffness in states of abnormal pulmonary blood flow and pressure. British Heart fournal, 24, 129.

Donald, K. W. (1959). Disturbances in pulmonary function in mitral stenosis and left heart failure. Progress in Cardiovascular Diseases, I, 298.

Donald, K. W., Bishop, J. M., and Wade, O. L. (1954). A study of minute to minute changes of arterio-venous oxygen content difference, oxygen uptake and cardiac output and rate of achievement of a steady state during exercise in rheumatic heart disease. Fournal of Clinical Investigation, 33, I 146.

Edelman, N. H., Cherniack, N., Lahiri, S., Braudo, L., and Fishman, A. P. (1968). The ventilatory response to hypoxia in cyanotic congenital heart disease. Clinical Research, 16, 369.

Evans, W., Short, D. S., and Bedford, D. E. (1957). Solitary pulmonary hypertension. British Heart fournal, 19, 93.

Fowler, N. O., Black-Schaffer, B., Scott, R. C., and Gueron, M. (I966). Idiopathic and thromboembolic pulmonary hypertension. American fournal of Medicine, 40, 33I.

Gazetopoulos, N., and Davies, H. (1966). Ventilatory response to exercise in patients with left-to-right shunts. British Heart fournal, 28, 590.

Gazetopoulos, N., Davies, H., and Deuchar, D. (1966a). Ventilation in relation to arterial and venous blood chemistry in heart disease. British Heart fournal, 28, 16.

Gazetopoulos, N., Davies, H., Oliver, C., and Deuchar, D. (1966b). Ventilation and haemodynamics in heart disease. British Heart fournal, 28, I.

Gazetopoulos, N., Samios, B., Paraskevas, G., and Tountas, K. (1972). Regulation of exercise ventilation in cyanotic congenital heart disease. In Proceedings of the 6th European Congress of Cardiology, Madrid. In the press.

Guz, A., Noble, M. I. M., Eisele, J. M., and Trenchard, D. (1970). Experimental results of vagal block in cardipulmonary disease. In Breathing: Hering-Breuer Centenary Symposium, p. 315. Ed. by R. Porter. J. and A. Churchill, London. 
Hurtado, A. (1964). Animals in high altitudes. In Handbook of Physiology. Section 4. Adaptation to the Environment, p. 843. American Physiological Society, Washington, D.C.

Jones, N. L., and Goodwin, J. F. (1965). Respiratory function in pulmonary thromboembolic disorders. British Medical fournal, r, 1089.

Kitchin, A. H., Lowther, C. P., and Matthews, M. B. (196I). The effects of exercise and of breathing oxygen-enriched air on the pulmonary circulation in emphysema. Clinical Science, 21, 93.

Mcllroy, M. B. (1959). Dyspnea and the work of breathing in diseases of the heart and lungs. Progress in Cardiovascular Diseases, $\mathbf{1}, \mathbf{2 8 4}$.

McIlroy, M. B., and Apthorp, G. H. (1958). Pulmonary function in pulmonary hypertension. British Heart fournal, 20, 397.

Penaloza, D., Sime, F., Banchero, N., Gamboa, R., Cruz, J., and Marticorena, E. (1963). Pulmonary hypertension in healthy men born and living at high altitudes. American fournal of Cardiology, 11, 150.

Rosenberg, S. A. (1964). A study of the etiological basis of primary pulmonary hypertension. American Heart fournal, 68, 484 .

Sackner, M. A., Akgun, N., Kimbel, P., and Lewis, D. H. (I964). The pathophysiology of scleroderma involving the heart and respiratory system. Annals of Internal Medicine, 60, 61I.

Severinghaus, J. W., Bainton, C. R., and Carcelen, A. (1966). Respiratory insensitivity to hypoxia in chronically hypoxic man. Respiration Physiology, I, 308

Shaw, D. B., Grover, R. F., Reeves, J. T., and Blount, G., Jr.
(1965). Pulmonary circulation in chronic bronchitis and emphysema. British Heart fournal, 27, 674 .

Sloman, G., and Gandevia, B. (1964). Ventilatory capacity and exercise ventilation in congenital and acquired cardiac disease. British Heart Fournal, 26, 121.

Storstein, O., Efskind, L., Müller, C., Rokseth, R., and Sander, S. (1966). Primary pulmonary hypertension with emphasis on its etiology and treatment. Acta Medica Scandinavica, 179, 197.

Trell, E. (1972). Primary and chronic thromboembolic pulmonary hypertension. Angiology, 23, 558.

Turino, G. M., Lourenso, R. V., Davidson, L. A. G., and Fishman, A. P. (1963). The control of ventilation in patients with reduced pulmonary distensibility. Annals of the New York Academy of Sciences, 109, 932.

Wade, O. L., and Bishop, J. M. (1962). Cardiac Output and Regional Blood Flow. Blackwell Scientific Publications, Oxford.

Walcott, G., Burchell, H. B., and Brown, A. L., Jr. (1970). Primary pulmonary hypertension. American fournal of Medicine, 49, 70.

Wessel, H. U., Kezdi, P., and Cugell, D. W. (1964). Respiratory and cardiovascular function in patients with severe pulmonary hypertension. Circulation, 29, 825.

Woolf, C. R. (1963). Pulmonary function in adults with intracardiac septal defect. Circulation, 27, 26r.

Requests for reprints to Dr. N. Gazetopoulos, Department of Cardiology, Aretaeion Hospital, 76 Vas. Sofias Avenue, Athens, Greece. 